\title{
Urinary Incontinence and Quality of Life in Female Patients with Obesity
}

\section{Incontinência urinária e qualidade de vida em pacientes femininas com obesidade}

\author{
Christiana Campani Nygaard ${ }^{1}$ Lucas Schreiner $^{1}$ Thiago Picolli Morsch ${ }^{1}$ Rodrigo Petersen Saadi ${ }^{1}$ \\ Marina Faria Figueiredo ${ }^{1}$ Alexandre Vontobel Padoin ${ }^{1}$ \\ ${ }^{1}$ Graduate Program in Medicine and Health Sciences, Pontifícia \\ Universidade Católica do Rio Grande do Sul, Porto Alegre, RS, Brazil \\ Rev Bras Ginecol Obstet 2018;40:534-539. \\ Address for correspondence Christiana Campani Nygaard, MD, \\ Pontifícia Universidade Católica do Rio Grande do Sul, Ipiranga 6690, \\ conjunto 712, 90610000, Porto Alegre, RS, Brazil \\ (e-mail: cnygcnyg@gmail.com).
}

\begin{abstract}
Keywords

- obesity

- urinary incontinence

- bariatric surgery

Resumo

Objective To analyze the prevalence of urinary incontinence (UI) in female patients with an indication for bariatric surgery, to investigate the potential risk factors and the impact on quality of life.

Methods A cross-sectional study with female patients with obesity. The evaluation consisted of a structured interview, a specific study form and quality of life questionnaires. The Poisson regression was performed to identify independent risk factors related to UI.

Results A total of 221 patients were enrolled; 118 of the study participants (53.4\%) reported UI episodes. Mixed UI (MUI), stress UI (SUI) only, and urgency UI (UUI) only were reported by $52.5 \%(62), 33.9 \%(40)$, and $13.5 \%$ (16) of these patients respectively. The prevalence of UI was increased by $47 \%$ among the women who had given birth vaginally and by $34 \%$ of the women who had entered menopause. Vaginal delivery and menopause were identified as independent risk factors related to UI. The mean International Consultation on Incontinence Questionnaire - Short Form (ICIQ-SF) score was $9.36 \pm 4$.9. The severity of symptoms was considered moderate in $53.3 \%$ (63) of the patients with UI.

Conclusion Urinary incontinence impacts quality of life negatively, and the prevalence of $\mathrm{UI}$ is high among obese patients. In the present study, vaginal delivery and menopause were independently associated with UI.

Objetivo Analisar a prevalência de incontinência urinária (IU), os fatores de risco e o impacto na qualidade de vida em pacientes femininas com indicação para realização de cirurgia bariátrica.

Métodos Estudo transversal com pacientes femininas obesas. A avaliação consistiu em entrevista estruturada, com questionários de estudo específico e de qualidade de vida. A regressão de Poisson foi utilizada para identificar os fatores de risco independentes para IU.
\end{abstract}

received

April 12, 2018

accepted

June 13, 2018
DOI https://doi.org/

$10.1055 / \mathrm{s}-0038-1670626$. ISSN 0100-7203.
Copyright $\odot 2018$ by Thieme Revinter

Publicações Ltda, Rio de Janeiro, Brazil
License terms

(c) (1) 
Palavras-chave

- obesidade

- incontinência urinária

- cirurgia bariátrica
Resultados Um total de 221 pacientes foram incluídos; 118 participantes (53.4\%) relataram episódios de IU. Incontinência urinária mista, IU de esforço e IU de urgência foram relatadas por $52.5 \%(62)$, $33.9 \%(40)$ e $13.5 \%(16)$ das pacientes, respectivamente. A prevalência de IU foi $47 \%$ maior em mulheres que tiveram parto vaginal, e $34 \%$ maior em mulheres que já entraram no período da menopausa. Parto vaginal e menopausa foram identificados como fatores de risco independentes para IU. A média da pontuação do International Consultation on Incontinence Questionnaire - Short Form (ICIQ-SF) foi de $9.36 \pm 4$ 4.9. A severidade dos sintomas foi considerada moderada em 53.3\% (63) das pacientes com IU.

Conclusão A IU impacta negativamente a qualidade de vida, e a prevalência de IU é maior em pacientes obesas. Neste estudo, parto vaginal e menopausa foram fatores de risco independentes para a ocorrência de IU.

\section{Introduction}

Obesity is a chronic disease with high prevalence that is difficult to manage. ${ }^{1}$ It is a public health problem, and up to 1.9 billion people are affected by obesity or overweightness. ${ }^{2}$ The prevalence of obesity has doubled since the 1980 s. $^{3}$ By $2016,39 \%$ and $13 \%$ of adults over 18 years of age were overweight and obese respectively. ${ }^{2}$ In the past, obesity was considered a problem found in developed countries; however, obesity and overweightness are currently drastically increasing in low- and middle-income countries, particularly in urban centers. ${ }^{2,3}$

Obesity is responsible for several adverse health effects, including increased morbidities and greater mortality. ${ }^{4}$ Elevated risks are already observed for overweight individuals, and increase progressively with the development of obesity. ${ }^{3}$ Obesity causes functional disabilities, reduced quality of life and reduced life expectancy, and is known to contribute to increases in chronic diseases, including cerebrovascular and cardiovascular diseases, diabetes, sleep apnea and pelvic floor dysfunctions. ${ }^{5,6}$ The negative effects of obesity on health include a strong association between obesity and urinary incontinence (UI). ${ }^{7}$

Obesity is the best established and most potentially modifiable risk factor in the development of UI. ${ }^{8} \mathrm{~A}$ positive association between UI and body mass index (BMI) has already been confirmed in certain studies. ${ }^{7,8}$ There is a clear dose effect of weight on incontinence, with each 5-unit increase in BMI associated with a 20 to $70 \%$ increase in incontinence risk. ${ }^{7}$ Compared with normal-weight patients, obese patients have approximately twice the risk of presenting with UI. ${ }^{9,10}$ Increased weight may aggravate or cause pelvic floor disorders by increasing both intra-abdominal pressure and chronic pressure on ligaments and nerves, leading to excessive stretching. ${ }^{11,12}$

In addition, there are other recognized risk factors for UI. There is an increase in the prevalence of UI during the perimenopausal period. ${ }^{9}$ Most studies show a peak prevalence of UI, particularly stress UI (SUI), between the ages of 40 and $60 .{ }^{13,14}$ Parity is another factor that is clearly associated with increased UI. ${ }^{10,15-17}$ Cesarean sections appear to have a protective effect; nevertheless, UI often presents during pregnancy, and this manifestation is a predictive factor for postpartum UI regardless of the delivery method. ${ }^{18,19}$ Fetal weight and advanced maternal age also appear to be risk factors for UI. ${ }^{20} \mathrm{~A}$ previous hysterectomy has been positively associated with the appearance of UI, although the only available data regarding this association are from observational studies. ${ }^{21}$

The aim of this study was to analyze the prevalence of UI in female patients with an indication for bariatric surgery and investigate potential risk factors.

\section{Methods}

The present study was conducted in a reference center for morbid obesity. Ethical and research approvals were obtained from the applicable local committee.

An informed consent form was offered to patients who satisfied the study criteria. To the patients it was promised that all data would remain confidential, and that the obtained results would only be used for scientific purposes. The participants were recruited between June 2016 and September 2017. A total of 221 female patients aged over 18 years old who had been assessed for bariatric surgery were enrolled in the present study.

The initial evaluation was performed using a structured interview and a specific study form. Symptoms and quality of life were assessed based on the interview, and the results of the validated Portuguese version of the International Consultation on Incontinence Questionnaire - Short Form (ICIQSF) and Kings Health Questionnaire. ${ }^{22}$ The patients who reported episodes of UI once a week or less were considered symptomatic. The anthropometric data, bioimpedance results, and medical histories were obtained from the medical records.

Statistical analyses were performed using the Statistical Package for the Social Sciences (SPSS, IBM Corp., Armonk, NY, US) software, version 21. Descriptive statistics (mean, median, standard deviation, and range) were used to present numerical variable values. Numbers and absolute and 
relative percentage frequencies were used to present categorical variables. The Mann-Whitney $U$ test was used to assess the statistical significance of differences between median values. Continuous data were analyzed using the Student $t$-test for related samples, and categorical variables were compared using chi-squared tests. Poisson regression was performed to identify independent risk factors related to UI. In the model, variables with $p$-values lower than 0.20 were included, and those with $p$-values lower than 0.10 were excluded. Multicollinear factors such as weight, excess weight, BMI, and waist circumference were incorporated into different models to improve the fit of the final model.

\section{Results}

During the study period, a total of 325 patients were identified as eligible subjects; 221 of these patients consented to participate and completed the baseline assessment. The patients were divided into 2 groups (Group 1, patients with UI; Group 2, patients without UI). A total of 118 patients (53.4\%) reported UI episodes.

The patients in Group 1 were significantly older than the patients in Group 2 (41.1 \pm 12.1 years versus $37.0 \pm 9.1$ years, $p=0.006$ ). Regarding the parameters used to evaluate the body composition of the patients, BMI, abdominal circumference and excess of weight were significantly higher in Group 1 than in Group 2. Menopause was more frequent in Group 1 than in Group 2 (23/116 (19.8\%) subjects versus 8/102 (7.8\%) subjects). These data are summarized in - Table 1.

A Poisson regression was performed to identify the independent risk factors related to UI (-Table 2). After an adjustment, the following factors were associated with UI: vaginal delivery $(p=0.044)$ and menopause $(p=0.031)$. Among women who had given birth vaginally and women who had entered menopause, the prevalence of UI was increased by $47 \%$ and $34 \%$ respectively. Smoking, excess weight and having delivered both vaginally and via caesarean section exhibited borderline associations with UI after the adjustment.

With respect to the patients with UI (Group 1), 40 (33.9\%), 16 (13.5\%), 62 (52.5\%), of these patients presented with SUI only, urgency UI (UUI) only, and mixed UI (MUI) respectively. The median urinary frequencies during the day and at night were 6 (5-8) voids and 2 (1-3) voids respectively, and 35/112 (31.2\%), of the patients used pads due to UI. Coital incontinence was reported by $12 / 111(10.4 \%)$. A total of $75 / 111$ $(67.6 \%)$ of the patients wanted a specific treatment for UI (-Table 3).

The results of the ICIQ-SF are described in - Table 4. The mean ICIQ-SF score was $9.36 \pm 4.9$. The severity of symptoms was considered moderate in 53.3\% (63) of the Group 1 patients. Most of these patients believed that they leaked small quantities: 79 (70.5\%) of urine. The highest scores of the 9 domains of the Kings Health Questionnaire were in the domains "Impact of Urinary Incontinence," "Measures of Gravity" and "General Perception of Health", with mean scores and standard deviations of $44.3 \pm 33.3,41.2 \pm 26.9$, and $43.2 \pm 21.5$ respectively.
Table 1 Baseline demographic and clinical characteristics of the patients according to urinary incontinence status

\begin{tabular}{|c|c|c|c|}
\hline Variables & $\begin{array}{l}\text { Patients } \\
\text { with UI } \\
(n=118)\end{array}$ & $\begin{array}{l}\text { Patients } \\
\text { without } \\
\text { UI }(n=103)\end{array}$ & p-value \\
\hline Age (years)* & $41.1 \pm 12.1$ & $37.0 \pm 9.1$ & 0.006 \\
\hline Weight $(\mathrm{kg})^{*}$ & $118.7 \pm 19.0$ & $114.8 \pm 17.5$ & 0.121 \\
\hline $\mathrm{BMI}^{*}$ & $45.9 \pm 7.6$ & $44.0 \pm 6.3$ & 0.043 \\
\hline $\begin{array}{l}\text { Waist } \\
\text { circumference* }\end{array}$ & $126.5 \pm 13.1$ & $122.8 \pm 12.9$ & 0.030 \\
\hline Waist-to-hip ratio* & $0.93 \pm 0.07$ & $0.93 \pm 0.19$ & 0.704 \\
\hline Fat mass* & $51.9 \pm 3.5$ & $51.5 \pm 4.1$ & 0.317 \\
\hline $\begin{array}{l}\text { Excess weight } \\
(\mathrm{kg})^{*}\end{array}$ & $53.8 \pm 18.3$ & $48.9 \pm 16.0$ & 0.041 \\
\hline $\begin{array}{l}\text { Basal metabolic } \\
\text { rate* }^{*}\end{array}$ & $1583 \pm 151$ & $1565 \pm 183$ & 0.439 \\
\hline Hypertension & $54 / 118(45.8)$ & $38 / 102(37.3)$ & 0.255 \\
\hline Diabetes & $24 / 118(20.3)$ & 14/103 (13.6) & 0.251 \\
\hline Asthma & $11 / 118(9.3)$ & $7 / 103(6.8)$ & 0.661 \\
\hline Dyslipidemia & 23/118 (19.5) & $22 / 103(21.4)$ & 0.860 \\
\hline Smoking history & $32 / 114(28.1)$ & 19/102 (18.6) & 0.161 \\
\hline Hysterectomy & $9 / 116(7.8)$ & 4/101 (4.0) & 0.374 \\
\hline Menopause & 23/116 (19.8) & $8 / 102(7.8)$ & 0.020 \\
\hline Sexual activity & $81 / 116(69.8)$ & $81 / 101(80.2)$ & 0.111 \\
\hline \multicolumn{4}{|l|}{ Parity } \\
\hline 0 & $31 / 116(26.7)$ & 39/103 (37.9) & \multirow[t]{3}{*}{0.208} \\
\hline $1-3$ & $75(64.7)$ & $57(55.3)$ & \\
\hline $4-7$ & $10(8.6)$ & $7(6.8)$ & \\
\hline \multicolumn{4}{|l|}{ Mode of delivery } \\
\hline Vaginal & $30(25.9)$ & $17(16.5)$ & \multirow[t]{4}{*}{0.088} \\
\hline $\begin{array}{l}\text { Cesarean } \\
\text { section }\end{array}$ & $35(30.2)$ & $36(35.0)$ & \\
\hline None & $31(26.7)$ & 39 (37.9) & \\
\hline Both & $20(17.2)$ & $11(10.7)$ & \\
\hline
\end{tabular}

Abbreviations: BMI, body mass index; UI, urinary incontinence. Note: *Data presented as mean \pm standard deviation; $p$-value calculated with the chi-squared test. All other data presented as number/total of patients (\%); p-value calculated with the chi-squared test.

Table 2 Multivariate analysis

\begin{tabular}{|l|l|l|}
\hline Variables & PR $(95 \% \mathrm{Cl})$ & $p$-value \\
\hline Smoking history & $1.28(0.98-1.66)$ & 0.071 \\
\hline Mode of delivery & 1.00 & \\
\hline None & $1.22(0.83-1.79)$ & 0.301 \\
\hline Cesarean section & $1.47(1.01-2.12)$ & 0.044 \\
\hline Vaginal & $1.41(0.94-2.10)$ & 0.095 \\
\hline Both & $1.34(1.03-1.76)$ & 0.031 \\
\hline Menopause & $1.00(0.99-1.01)$ & 0.073 \\
\hline Weight excess &
\end{tabular}

Abbreviations: $95 \% \mathrm{Cl}$, 95\% confidence interval; PR, prevalence ratio. 
Table 3 Data related to urinary incontinence

\begin{tabular}{|l|l|}
\hline & $\begin{array}{l}\text { Patients with UI } \\
(N=118)\end{array}$ \\
\hline SUI only & $40(33.9)$ \\
\hline UUI only & $16(13.5)$ \\
\hline MUI & $62(52.5)$ \\
\hline Coital UI & $12 / 111(10.4)$ \\
\hline Frequency* & $6.0(5-8)$ \\
\hline Nocturia* & $2(1-3)$ \\
\hline Use of incontinence pads & $35 / 112(31.2)$ \\
\hline Desire for a specific treatment & $75 / 111(67.6)$ \\
\hline
\end{tabular}

Abbreviations: MUI, mixed urinary incontinence; SUI, stress urinary incontinence; UI, urinary incontinence; UUI urgency urinary incontinence.

Note: *Median (range); other data presented as number/total of patients (\%).

Table 4 ICIQ-SF scores

\begin{tabular}{|c|c|}
\hline & $\begin{array}{l}\text { Patients with UI } \\
(N=118)\end{array}$ \\
\hline Total score ${ }^{*}$ & $9.36 \pm 4.9$ \\
\hline \multicolumn{2}{|l|}{ Severity } \\
\hline Slight (1-5) & $29(24.5)$ \\
\hline Moderate (6-12) & $63(53.3)$ \\
\hline Severe $(13-18)$ & $19(16.1)$ \\
\hline Very severe(19-21) & $7(5.9)$ \\
\hline \multicolumn{2}{|l|}{ Frequency of urine leakage } \\
\hline Once a week or less & $37(31.5)$ \\
\hline Twice to three times a week & $31(26.1)$ \\
\hline Once a day & $14(11.8)$ \\
\hline Several times a day & $24(20.3)$ \\
\hline All the time & $7(5.9)$ \\
\hline \multicolumn{2}{|l|}{ Amount of urine leaked } \\
\hline Small & $79(70.5)$ \\
\hline Moderate & $26(23.2)$ \\
\hline Large & $7(6.3)$ \\
\hline $\begin{array}{l}\text { Leaks before patient can } \\
\text { get to the toilet }\end{array}$ & $70(62.5)$ \\
\hline $\begin{array}{l}\text { Leaks when patient coughs } \\
\text { or sneezes }\end{array}$ & 85 (75.9) \\
\hline Leaks when patient is asleep & $20(17.9)$ \\
\hline Leaks when patient is exercising & $31(27.7)$ \\
\hline Leaks after patient urinates & $34(30.4)$ \\
\hline Leaks for no obvious reason & $23(20.5)$ \\
\hline Leaks all the time & $4(3.6)$ \\
\hline
\end{tabular}

Abbreviations: ICIQ-SF, International Consultation on Incontinence Questionnaire - Short Form; UI, urinary incontinence.

Note: ${ }^{*}$ Total score $=$ sum of questions 1, 2 and 3; other data presented as number/total of patients (\%).

\section{Discussion}

Urinary incontinence impacts quality of life negatively, and the prevalence of UI is high in patients with obesity. In the present study, UI affected more than half $(53.4 \%(118))$ of the patients with obesity; this finding was in agreement with previously reported results. ${ }^{23}$

Urinary incontinence was more prevalent in patients after menopause. The patients in Group 1 were older than those in Group 2, and this was statistically significant, although the difference was not a marked one. Since the tissues involved in the female urinary continence mechanism are sensitive to estrogen, estrogen deficiency after menopause may be an etiological factor in the development or progression of UI. ${ }^{24}$ This effect did not appear to be attenuated by the peripheral conversion of estrogen, which is particularly common in patients with obesity. ${ }^{25}$

Vaginal delivery was the other independent factor associated with a higher prevalence of UI. As it has been observed in other studies, this effect was most evident in the third and fourth decades of life, but was attenuated in middle age and absent for elderly subjects. ${ }^{13,26,27}$ Thus, the aforementioned finding could be explained by the fact that the mean ages of the examined subjects were $41.1 \pm 12.1$ years versus $37.0 \pm 9.1$ years for Group 1 and Group 2 respectively.

Urinary incontinence was more common in patients with higher BMIs, excess of weight and waist circumference. In most studies, a strong association is observed between increasing weight and UI. Each 5-unit increase in BMI was associated with $\sim 20$ to $70 \%$ increase in the risk of daily incontinence. ${ }^{7}$ However, in our sample, in which all of the patients had obesity, none of those parameters were independently related to UI.

The most prevalent type of UI observed in the present study was MUI, followed by SUI. The association between UI and obesity is known to be stronger for SUI and MUI and more modest for UUI. ${ }^{9,28-30}$ Cohort studies have also suggested that an earlier appearance of obesity is associated with a higher probability of developing UI in middle age. ${ }^{31}$ There is evidence that obesity increases the incidence of SUI, but increases in metabolic syndrome are more strongly associated with IUU..$^{32}$ Increased weight may aggravate or cause pelvic floor disorders by increasing intra-abdominal pressure and chronic pressure on ligaments and nerves, leading to excessive stretching. ${ }^{11,12}$

This study benefits from the use of a validated incontinence questionnaires, which enable the differentiation of incontinence type, frequency, and severity based on the selfreports of the patients. The use of this type of questionnaire allows for better interpretation of the impact that patients' symptoms have on their quality of life.

Another strength of our study is the number of obese patients who were enrolled. In many studies, an obese population is compared with a normal BMI population. Our data are from patients with a mean BMI of class III obesity.

An important limitation is the lack of an objective outcome to compare with subjective measures. Our data could 
be stronger had we performed a pad test and/or an urodynamic assessment.

Obesity is known to be associated with many medical issues. Recently, the association between obesity and UI, which impacts quality of life, has been widely researched. The impact of obesity on pelvic floor function and consequently UI cannot be underestimated. This effect is particularly relevant at the present time, given the increasing prevalence of obesity and, therefore, UI. Urinary incontinence is more than twice as prevalent as diabetes and dyslipidemia, and is more prevalent than hypertension. In this study, most of the patients with UI stated that they wanted a specific treatment for their symptoms; such treatment needs to be offered by health professionals.

\section{Conclusion}

In our sample of patients with obesity, UI was highly prevalent and greatly impacted quality of life. In the present study, vaginal delivery and menopause were independently associated with a higher prevalence of UI.

Conflicts of Interest

The authors have none to declare.

\section{References}

1 Deitel M. Overweight and obesity worldwide now estimated to involve 1.7 billion people. Obes Surg 2003;13(03):329-330 Doi: 10.1381/096089203765887598

2 Obesity: preventing and managing the global epidemic. Report of a WHO consultation. World Health Organ Tech Rep Ser 2000;894: i-xii, 1-253

3 World Health Organization. Obesity and Overweight. Geneva: WHO; 2016. http://www.who.int/news-room/fact-sheets/detail/ obesity-and-overweight. Accessed October, 2017.

4 Sjöström L, Peltonen M, Jacobson P, et al. Association of bariatric surgery with long-term remission of type 2 diabetes and with microvascular and macrovascular complications. JAMA 2014;311 (22):2297-2304 Doi:10.1001/jama.2014.5988

5 Ul-Haq Z, Mackay DF, Fenwick E, Pell JP. Meta-analysis of the association between body mass index and health-related quality of life among adults, assessed by the SF-36. Obesity (Silver Spring) 2013;21(03):E322-E327 Doi:10.1002/oby.20107

6 Colquitt JL, Pickett K, Loveman E, Frampton GK. Surgery for weight loss in adults. Cochrane Database Syst Rev 2014;(08):CD003641 Doi:10.1002/14651858.CD003641.pub4

7 Subak LL, Richter HE, Hunskaar S. Obesity and urinary incontinence: epidemiology and clinical research update. J Urol 2009; 182(6, Suppl)S2-S7 Doi:10.1016/j.juro.2009.08.071

8 Hunskaar S. A systematic review of overweight and obesity as risk factors and targets for clinical intervention for urinary incontinence in women. Neurourol Urodyn 2008;27(08):749-757 Doi:10.1002/nau.20635

9 Hannestad YS, Rortveit G, Sandvik H, Hunskaar S; Norwegian EPINCONT study. Epidemiology of Incontinence in the County of Nord-Trøndelag. A community-based epidemiological survey of female urinary incontinence: the Norwegian EPINCONT study. Epidemiology of Incontinence in the County of Nord-Trøndelag. J Clin Epidemiol 2000;53(11):1150-1157

10 Grodstein F, Fretts R, Lifford K, Resnick N, Curhan G. Association of age, race, and obstetric history with urinary symptoms among women in the Nurses' Health Study. Am J Obstet Gynecol 2003; 189(02):428-434 Doi:10.1067/S0002-9378(03)00361-2
11 Swenson CW, Kolenic GE, Trowbridge ER, et al. Obesity and stress urinary incontinence in women: compromised continence mechanism or excess bladder pressure during cough? Int Urogynecol J Pelvic Floor Dysfunct 2017;28(09):1377-1385 Doi:10.1007| s00192-017-3279-6

12 Richter HE, Creasman JM, Myers DL, Wheeler TL, Burgio KL, Subak LL; Program to Reduce Incontinence by Diet and Exercise (PRIDE) Research Group. Urodynamic characterization of obese women with urinary incontinence undergoing a weight loss program: the Program to Reduce Incontinence by Diet and Exercise (PRIDE) trial. Int Urogynecol J Pelvic Floor Dysfunct 2008;19(12):1653-1658 Doi:10.1007/s00192-008-0694-8

13 Hunskaar S, Lose G, Sykes D, Voss S. The prevalence of urinary incontinence in women in four European countries. BJU Int 2004; 93(03):324-330 Doi:10.1111/j.1464-410X.2003.04609.x

14 Irwin DE, Milsom I, Hunskaar S, et al. Population-based survey of urinary incontinence, overactive bladder, and other lower urinary tract symptoms in five countries: results of the EPIC study. Eur Urol 2006;50(06):1306-1314, discussion 1314-1315 Doi:10.1016/j. eururo.2006.09.019

15 Danforth KN, Townsend MK, Lifford K, Curhan GC, Resnick NM, Grodstein F. Risk factors for urinary incontinence among middleaged women. Am J Obstet Gynecol 2006;194(02):339-345 Doi:10.1016/j.ajog.2005.07.051

16 Waetjen LE, Liao S, Johnson WO, et al. Factors associated with prevalent and incident urinary incontinence in a cohort of midlife women: a longitudinal analysis of data: study of women's health across the nation. Am J Epidemiol 2007;165(03):309-318 Doi:10.1093/aje/kwk018

17 Rortveit G, Hannestad YS, Daltveit AK, Hunskaar S. Age- and typedependent effects of parity on urinary incontinence: the Norwegian EPINCONT study. Obstet Gynecol 2001;98(06):1004-1010 Doi:10.1016/S0029-7844(01)01566-6

18 Press JZ, Klein MC, Kaczorowski J, Liston RM, von Dadelszen P. Does cesarean section reduce postpartum urinary incontinence? A systematic review. Birth 2007;34(03):228-237 Doi:10.1111/ j.1523-536X.2007.00175.X

19 Tähtinen RM, Cartwright R, Tsui JF, et al. Long-term impact of mode of delivery on stress urinary incontinence and urgency urinary incontinence: a systematic review and meta-analysis. Eur Urol 2016;70(01):148-158 Doi:10.1016/j.eururo.2016.01.037

20 Rortveit G, Hunskaar S. Urinary incontinence and age at the first and last delivery: the Norwegian HUNT/EPINCONT study. Am J Obstet Gynecol 2006;195(02):433-438 Doi:10.1016/j. ajog.2006.01.023

21 Forsgren C, Lundholm C, Johansson AL, Cnattingius S, Zetterström J, Altman D. Vaginal hysterectomy and risk of pelvic organ prolapse and stress urinary incontinence surgery. Int Urogynecol J Pelvic Floor Dysfunct 2012;23(01):43-48 Doi:10.1007/s00192011-1523-z

22 Tamanini JT, Dambros M, D’Ancona CA, Palma PC, Rodrigues Netto $\mathrm{N}$ Jr. [Validation of the "International Consultation on Incontinence Questionnaire - Short Form" (ICIQ-SF) for Portuguese]. Rev Saude Publica 2004;38(03):438-444 Doi:10.1590/S0034-891020 04000300015

23 Subak LL, King WC, Belle SH, et al. Urinary incontinence before and after bariatric surgery. JAMA Intern Med 2015;175(08): 1378-1387 Doi:10.1001/jamainternmed.2015.2609

24 Cody JD, Jacobs ML, Richardson K, Moehrer B, Hextall A. Oestrogen therapy for urinary incontinence in post-menopausal women. Cochrane Database Syst Rev 2012;10:CD001405 Doi:10.1002/ 14651858.CD001405.pub3

25 Vicennati V, Garelli S, Rinaldi E, et al. Obesity-related proliferative diseases: the interaction between adipose tissue and estrogens in post-menopausal women. Horm Mol Biol Clin Investig 2015;21 (01):75-87 Doi:10.1515/hmbci-2015-0002

26 Chiarelli P, Brown W, McElduff P. Leaking urine: prevalence and associated factors in Australian women. Neurourol Urodyn 1999; 
18(06):567-577 Doi:10.1002/(SICI)1520-6777(1999)18:6<567: AID-NAU7>3.0.CO;2-F

27 Miller YD, Brown WJ, Russell A, Chiarelli P. Urinary incontinence across the lifespan. Neurourol Urodyn 2003;22(06):550-557 Doi:10.1002/nau.10023

28 Persson J, Wolner-Hanssen P, Rydhstroem H. Obstetric risk factors for stress urinary incontinence: a population-based study. Obstet Gynecol 2000;96(03):440-445 Doi:10.1016/S0029-7844(00)00950-9

29 Brown JS, Grady D, Ouslander JG, Herzog AR, Varner RE, Posner SF. Prevalence of urinary incontinence and associated risk factors in postmenopausal women. Heart \& Estrogen/Progestin Replacement Study (HERS) Research Group. Obstet Gynecol 1999;94(01): 66-70
30 Kuh D, Cardozo L, Hardy R. Urinary incontinence in middle aged women: childhood enuresis and other lifetime risk factors in a British prospective cohort. J Epidemiol Community Health 1999; 53(08):453-458

31 Dallosso HM, McGrother CW, Matthews RJ, Donaldson MM; Leicestershire MRC Incontinence Study Group. The association of diet and other lifestyle factors with overactive bladder and stress incontinence: a longitudinal study in women. BJU Int 2003;92 (01):69-77 Doi:10.1046/j.1464-410X.2003.04271.X

32 Tai HC, Chung SD, Ho CH, et al. Metabolic syndrome components worsen lower urinary tract symptoms in women with type 2 diabetes. J Clin Endocrinol Metab 2010;95(03):1143-1150 Doi:10.1210/jc.20091492 